\title{
The Verb and Proverb in Chinua Achebe's Things Fall Apart
}

\author{
By Rachid Neji
}

\begin{abstract}
The present essay surveys the present position of African articulation with respect to its effects on the formulation of the linguistic identity. For this purpose, one puts gloss on Chinua Achebe's Things Fall Apart that includes an ambiguous devotion to myriad technical and narrative devices to debunk the yoke of the British Empire. The essay argues that, in contrast to classical writers in the field of fiction, the Anglophone novelists have been much more resistant to the colonial doctrines of selective classification. In fact, the African authors do not only fade the conventional rules but they increasingly endorse the public desired narration wherein literariness includes free generic mixed tools. The postcolonial text becomes subversive and creative. The essay exposes a critical discussion of the previous premises of articulation and its bearing upon asserting an independent textual selfhood devoid of the colonial limitations. The gist seems to leave the ground for building a creative local voice with public desired qualities. Thus, the fact of blending the local with the public leaves room for blending the word and the world, the inside and the outside, the Joy and the loss. This paper comprises a conspicuous consideration of Achebe's notion of African communication through pristine artistic text.
\end{abstract}

Keywords: history, identity, classicism, postcolonial, articulation, artistic, loss

\section{Introduction}

Chinua Achebe is considered to be the father of modern African literature. In his writings, the Nigerian author delves into the European colonization in the wake of two world wars. This orientation pervades all of his works, which purely reflect African dignity and value. Thus Achebe is, no doubt, an obvious writer whose writings reflect and foreshadow richly the miserable contextual realities of African people. In this regard, Achebe declares that the motivation behind this work of art is to introduce a real and dynamic African society to a Western audience who perceived African mind as primitive and backward.

Since its first appearance in 1958, Chinua Achebe's Things Fall Apart has received wide range of critical stand points. In fact, this novel tells the story of Okonkwo, a stoic clan leader and former wrestling hero who comes back to his village after bitter years in exile. He never shows any sign of fear or weakness. Okonkwo is described as fearless, powerful wrestler and meaning so much to village as it is stated in the following lines.

Okonkwo was well known throughout the nine villages and even beyond. His fame rested on solid personal achievements. As a young man of eighteen he had brought honor to his village by throwing Amalinze the Cat. Amalinze was the great wrestler

\footnotetext{
*Assistant, Higher Institute of Human Sciences Medenine, Tunisia.
} 
who for seven years was unbeaten, from Umuofia to Mbaino. Okonkwo was clearly cut out for great things.... Although Okonkwo was still young, he was already one of the greatest men of his time. Age was respected among his people, but achievement was revered (Achebe 1996, pp. 3, 8).

In the novel, Okonkwo does many actions in order to prove that he is a "real man" and able to achieve the dreams of his tribe. He always pretends to be strong and powerful. However, it appears that this pomposity will guide him to a possible downfall. In this sense, the novel delineates the Igbo people at a truly important stage in their history and culture. In fact, colonial forces apply pressure and look for power. The colonial forces basically proclaim the end of African traditional consciousness ranging from religion, family unit and gender relations. Colonial voices do not come to control the uncontrolled, rather they long for preaching a new conceptualization that ends with the patriarchal knowledge. In this regard, the author attempts to portray the postcolonial African reality in all its varied versions and to find out the extent to which this work of fiction reflects the aspirations of the African community.

Since the novel belongs to the Anglophone tradition, the work combines a sort of narration, proverbs; old values which are brought to lay bare the Western new belief and orientation. The African traditional songs convey the traditional folklore and provide a suitable realm to highlight the dominant features of the novelist's anti-colonial discourse as well as system. Such a process can be understood as the result of Achebe's fashioning of a private linguistic identity capable of representing the African pristine universe and better to boycott the search of a selfhood in the pre-colonial area. Giving the important value of Achebe's literary work, the present study endeavors to explain the linkage between the linguistic discourse and African selfhood. The main interest is to orchestrate a background of knowledge able to subvert the colonial ideologies and assert a proper African realm based on the freedom of consciousness and belief.

\section{Theoretical Assumption}

Many contemporary critics have dealt with postcolonial studies among them is Mikhail Bakhtin who treats the colonial and postcolonial discourse from a dialogic approach. To this exception, the effect of "situating the work of Mikhail Bakhtin in relation to contemporary literary, theoretical, and philosophical discourse is in no way a straightforward proposition" (Miller et al. 2001). This is due to his emphasis on the necessity of giving voice to marginalized texts and taking them as leading insights in the development of narrative multiplicity. The scheme emphasizes the importance of avoiding single interpretation and unique theoretical perspective while approaching colonial context. He asserts that a critic should thoroughly investigate a various number of cultural dialectics and orientations.

For Bakhtin, language turns out to be an obvious tool depicting the greater interrelated body of postmodern discourse. The discursive power interaction appears to be responsible of devising meaning, identity and reality on different 
levels. In other words, Bakhtin focuses on the foregrounding the colonized language against the background of past categorization produced by the colonizer in the colonial era. Thus, he puts gloss on the discourse of post-colonialism and the stylistic features to highlight the hidden space of meaning.

To put it another way, such a space of linguistic expression is the outcome of multiple structures. This process produces complex signs or symbols which are necessary to decode new avenue of thoughts. This intention by the postcolonial critic is in affinity with Derrida's theory of difference. To reinforce this vicinity, it Jacques Derrida suggests that, "it is because of difference that the movement of signification is possible" (qtd. in Bass and Différance 1982, p. 13). The assumption is based on the fact that the postmodern fragmentation affects the structural components which ultimately lead to the denial of objectivity in that culture and identity. In Bakhtin's point of view, in order to study a postcolonial subject, the critic should pay attention to hybrid identities within the space of discourse. Moreover, he should recognize how through the technique of differentiation a dependent subject is to be freed from the yoke of the colonizer.

In this sense, Bakhtin's reading of postcolonial discourse puts the finger on two particular purposes. The first one is to assert otherness and give voice to the colonized subject. The second aim lies in transcending the discourse of colonial power towards establishing a resistant identity, polyphonic and carnivalestic discourse. Dentith (1993) deems that this situation cannot be reached unless has been "a plurality of independent and unmerged voices and consciousnesses, a genuine polyphony of fully valid voices" (Dentith 1993, p. 7). The main motivation resides in establishing a rhetoric realm wherein the marginalized subject voices and confirms his linguistic existence to a public audience.

Actually, the postcolonial discourse seeks to debunk grand narratives and bypass the power of ideology. So, in applying his conception, the postcolonial writer belittles the authority of ideology in the construction of meaning at different levels. Similarly, Bakhtin advocates social dialogues and active voices, which are able to record and narrate independent discourses. In fact, Polyphonic text should reflect reality through linguistic features. In this sense, an ideal novel comprises a dialogic interaction between the supposed authorial voice and those belonging to the margin. Therefore, discursive authenticity is related to this linguistic as well as meaningful intrusion.

In addition, Bakhtin puts the stress on the power of carnivalesque as well as celebration. This narrative technique combines the past with the present, the colonial with the postcolonial, and the sacred with the profane in order to establish a discursive area of differentiation and acceptance. A "polyphonic novel" that unites the differences deserves to host new dialogism based on juxtaposition, negotiation and authenticity (Bakhtin1984, p. 39). This conceptualization clarifies Bakhtin's understanding of the narrative reality. In this sense, one can deliver that in Bakhtin's point of view truth is not singular, linear and universal. However, reality and certitude should reflect the variety of voices in society. Thus, the critic seeks to fashion an open text wherein the public interferes with the particular, the dominant negotiates with the margin, and the context interacts with the text. 
As stated earlier what is of paramount importance is to make sense of the circumstances under which the novelist has managed to write an alternative discourse in order to haunt the discursive dominance and to ironize the British atrocity in his Things Fall Apart. Plainly, putting this literary work in center and reading it based on the philosophy of Bakhtin, the major tenor of the present study is to expand the territorial perception about the author and how he has framed his innovation in his narrative texture.

\section{Discussion}

A new discourse cannot possess an aura without prioritizing the linguistic and grammatical features of the language in which it is introduced. In this sense, language plays an important role in the construction of a national literature and the deconstruction of colonial shackles. That is why, in the 1950s and 1960s when the African marches for emancipation were reaching their peak, the dilemma of weaving a proper African language gained full concentration in order to oppose the dominant colonial hegemony.

What is really needed appears to be a language that is capable of expressing the oral and written African literature. Achebe's main target is to elucidate through his literary works the urgent need to construct an African discourse with a capacity to bring insight both to non-African readers, writers and critics. This orientation paves the way for debunking colonial signs and establishing an African local written narration. Plainly, a postmodern African voice that is fertile with key concepts such as transcendence, emancipation, metamorphosis and subversion.

Notably, Achebe's achieves a sort of success in the creation of a proper African language. This is due to his wide dealing with the Nigerian traditions. He is conscious of the clash between the pre-colonial traditions and the postmodern. The very consciousness arouses the necessity to create an African voice freed of the whiteness and blackness ideologies. The author seeks to promote a discourse of otherness promoted by the white new colonizers and the oral African literature. Achebe wants to inculcate the idea that the Nigerian literary writers should benefit from their past and find luminous insights in spite of all its imperfections. This movement paves the ground for devising an alternative discourse based on a proper African linguistic background.

In Things Fall Apart, Achebe's specificity lies in his choice of the English language to portray the dark side of the colonizers. This intention is caused by the linguistic power of this language and its ability to welcome the African discursive production and the British narrative features. The novelist incorporates the African oral images to the English language as a unifying discursive tool. The author does not long for putting an end to the oral literary potential of African storytellers. However, Achebe wants to make these stories available in a written linguistic corpse. Thus, one can assert that Achebe's choice for writing African traditions while using English language is a sort of linguistic and postcolonial awareness. The author's discourse adopts a language that catches the attention of myriad 
readers. This language makes reference to African dialects and proverbs in order to satirize and ironize the colonial history and literature.

The specific point in Achebe's strategy lies in reproducing attributes of African oral tradition into an official anti-colonial discourse. As a matter of fact, Achebe uses the colonial language as a discursive weapon to fight the narrative hegemony of the white authorial voice. His emphasis on using English clarifies his deep critical attitude towards the narratives of colonial writers. Achebe's reappropriates the beauty of African dialects in a colonial language to lay bare the atrocity and hypocrisy of the new comers. Then, the linguistic recurrence becomes a sort of deconstruction and construction of a new postcolonial future.

The first characteristic in the case of Chinua Achebe's language is that the discursive features of the novel derive from the Igbo proverbs. These stories are artistically used through an act of literal translation and without deviating from the English language. As a matter of fact, this artistic contemplation seems to be the gist of vocabulary selectiveness. The author transforms the strange word and syntax into meaningful structures. The very transformation of the linguistic properties appears to be appreciated by the non-Igbo English critics providing that it constitutes a fundamental background of cultural linkage between colloquial dialect and standard language. These African proverbs are re-appropriated to enlighten the linguistic and cultural realities of Igbo people.

In the novel, one can find "a toad does not run in the daytime for nothing" (Achebe 1996, p. 15) and "a child fingers are not scalded by e piece of hot yam which its mother puts into its palm". In fact, proverbs are manifestation of African narrative civilization. This oral literature is resurrected to situate Achebe's discourse within the context of postcolonial literature written in standard language. For instance, Fanon (1993) sustains that, "there was nothing to be ashamed of in the past, but rather dignity, glory and solemnity. The claim to a national culture in the past does not only rehabilitate that nation and serve as a justification for the hope of a future national culture" (Fanon 1993, p. 169). This optimistic attitude is shared by Achebe who uncovers the splendid past of Nigeria through remembering the pre- colonial Igbo culture.

Achebe's recurrence of the African mythological stories and strange words is a manifestation as well as revitalization of the African lost culture. The author wants to infuse life into the African history after the hegemonic presence of the colonizers language. The writer endeavors to search for the literariness in the Igbo native tongue in order to expose it and show its power as a weapon to fight the power of the colonizers. Stories, folktales and myths identify African peculiarity and append to the path of independence.

It is evident that Achebe centralizes the Igbo proverbs to reveal its discursive power. The African dialect is used as rhetorical device to insist on its linguistic charm for the universal readers. For instance, Okonkwo's father's speech to Okoye "Among the Igbo the art of conversation is regarded very highly and proverbs are the palm-oil with which words are eaten". (Trilogy 7) suggests the fact that Achebe seems to be proud of the African historical memory. Clearly, the author's main target is to unite these historical fragments into a linguistic and original organic unit. 
In addition, the author incorporates folklore stories as discursive devices to preach a new discourse of the colonized African people. According to Achebe, stories are the backbone of African society. These stories are linguistically modified in order to introduce the African language to European readers. This scheme stands for the only shelter to protect the past from the dominant discourse of the colonizer. In fact, the author re-invigorates the African tales and the Igbo stories and he endeavors to expose them through using a simple narrative style. The very simplicity is meant to highlight forgettable storytelling techniques.

Moreover, one can confirm that Achebe's resurrection of African stories plays a fundamental role in weaving the discursive and thematic functions of the novel. These tales explain the artistic craft of the African authors while introducing the trauma of colonization. For instance, the story of Snake-Lizard in the ninth chapter shows the writer's insistence on providing language with a literary aura. Achebe seeks to persuade the reader of the colonizer's danger towards the natives. Similarly, the above story narrates Okonkwo's wife food. She cooks and tells stories to her daughter. Indeed, the mother prepares food and tells a specific story. What can be deduced from this movement is that for African people food cannot hide the colonial danger. What the African people want is dignity and justice within their filched land.

The author emphasizes the fact that African people cannot forget their past memories. This history is saved inside the mother's heart and father's mind. Forgetting and forgiveness seem to be a sort of imagination. Forgetting leads to the loss of punishment and resurrection. Forgiveness leaves no room for celebration. That's why, the mother narrates and Achebe writes her stories to the world in order to insist on the positive presence of historical events. This narrative collusion is only meant to ironize the present colonial hypocrisy. Thus, language appears to be the main bridge for humorous and harmonious linguistic, political and historical constructions.

Things Fall Apart appears to be a response to earlier colonial period of African land. For this reason, Achebe's choice of language is functional as well as political. While some later African authors voice the native African languages as a form of resistance to colonialism, Achebe wants to achieve cultural revitalization through the use of the colonial signifier. His ability to ape the rhythm of the Igbo language assists him in using Igbo proverbs, folktales and vocabulary in the novel. In fact, Igbo proverbs are entirely native and they comprise native wisdom. In addition, Folktales are important components of the Nigerian oral tradition. Then, this re-appropriation makes the African tradition and Igbo liberation go through the process of oral and linguistic identification.

Furthermore, in order to expose the misery of Igbo tribe, Achebe foregrounds the African diction. In fact, the author inserts a series of Igbo words into the English text. This linguistic strategy is used to introduce the cultural, religious and social specifications of Umuofia people. These devices are inserted by the author to build a rhetoric area on the basis of a foreign language. The postcolonial writer seeks to localize the African dialect, history and story within a standard linguistic system. For example, in chapter seven, Okonkwo introduces the following African song: 
Sala

Eze ilikwa ya Ikwaba akwa ogholi

Ebe Danda nechi eze Ebe Uzuzu nete egwu Sala (Achebe 1996, p. 60).

In fact, the writer seizes the opportunity to represent the tradition of Igbo life. This presentation is done through the use of a worldwide language in order to seduce the universal readers. The postcolonial author is no longer dead or lost in the myriad narrative voices. However, Achebe lives with the dream to subvert the colonial power and assert the beauty of African people. This dream comes to reality through a colonial linguistic power and the craft of colonized other. Then, otherness is no longer a passive subject and submissive ego. It becomes sign of strength and hegemony.

Obviously, it can be asserted that the African author has attempted to construct a discursive universe able to induce and expose the positive aspects of homogenous discourse. Achebe's target is to provide an alternative narrative construction capable of demolishing the colonial text. The writer's reference to past stories constitutes the backbone of a post-colonial construction alongside with its optimistic repercussions which foreshadow for an independent Nigerian national literature.

Another postmodern philosophical technique dominates Achebe's novel. The device stresses the death of the author and the multiplicity of voices. It shows the richness of postcolonial discourse and its compactness. In fact, the technique surges from Bakhtin's philosophy of multiple voices within the text. In this sense, Okonkwo's voice appears to be dominant in Things Fall Apart. This vocal dominance cannot hide the appearance of other related minor voices. This interaction appears to be specific and original within postcolonial discourse. It means that concepts such as authorship and centrality disappear. What comes next can be explained into Bakhtin's theory of Polyphony.

In this regard, the multiplicity of voices generates the presence of an absent voice and the appearance of a disappeared history. Achebe seeks to pave the way for polyphonic discourse wherein opposing events can conflate and promote in spite of the hidden difference. For the author, the deconstruction of colonization must be followed by myriad steps of tolerance and equality. This process conveys a mirage and sort of sublimation. However, the acceptance of otherness, the overcoming of colonial shackles and the submissiveness to recent metamorphism is sufficient to achieve positive vibes within a universe of turmoil as well as anarchy.

Going beyond the surface level and taking into consideration the narrative voice, one can deliver that Achebe's deconstruction of authorship is mainly meant to stigmatize the classical patriarchal system. In fact, the concept of patriarchy stresses the superiority of masculinity over femininity. In Things Fall Apart, Okonkwo deeply believes in this conceptualization. He goes on to show his power and strength as a leader to Umuofia tribe. The intention of leadership leads him to neglect the history of his father "Unoka". This hatedrness can be related to the writer's wish to end with patriarchal society. This historical divorce includes the subversion of the colonial leadership and the construction of an African land with a specific history, language as well as identity. The construction will undo with 
traditional notions of inferiority and otherness. It will pay lip service to a body of social and linguistic discourse wherein language and society are intertwined. For instance, Achebe's creation is expressed by the following declaration in Things

\section{Fall Apart}

"It's true that a child belongs to its father. But when a father beats his child, it seeks sympathy in its mother's hut. A man belongs to his fatherland when things are good and life is sweet. But when there is sorrow and bitterness he finds refuge in his motherland. Your mother is there to protect you. She is buried there. And that is why we say that mother is supreme" (Achebe 1996, p. 124).

Such a confirmation may be seen as the reason beyond the novelist's tendency to defend and constitute a social, historical and linguistic dialogue with the colonial system to protect his motherland and foreground the mother tongue. It should be highlighted that the negotiation with the 'white man' brings about double optimistic results. The first one lies in laying bare the hypocritical aspect of the supposed colonial civilization. The second delivers that the pre-colonial area was a period free of bias or presumptions.

One can deduce that Achebe's novel is a palpable demonstration of "collapse, breaking into pieces, chaos, and confusion" (Alimi 2012, p. 121). In fact, the difference between Achebe's novel and other colonial novels is that his book thoroughly describes Igbo society as he introduces them in a manner which exposes all aspects of Igbo universe and not only the optimistic aspect of their culture. He also looks for building a linkage between Igbo society and the white missionaries to take control of Umuofia.

The Igbo depend on their language to differentiate their quality from the white colonizers. They also use ambiguous language to define their presence in the postmodern society. The linkage between language on the one hand and culture on the other can only explain the virginity of pre-colonial era and the atrocity of colonial action. This is because verbs and proverbs complete each other and succeed in defining the gist of dilemma. Neither language nor culture can lay bare the colonial reality without the craft and artistic orientation of the author. Hence, Achebe's treatment and description of African people can obviously be appreciated in the way he linguistically represents their experiences, stories and realities. In most instances, one can confirm that the essence of African resistance can be measured by the power of history and the visibility of language.

To expose the native moral values, Achebe recurs to the use of the colonial language. In this sense, The English language plays the role of introducing Igbo's traditions. Achebe feels that language is a linguistic power responsible for ironizing the colonial hypocrisy and empowering the colonized weakness. It will be able to narrate the unsaid and put light on the dark side of the African experience. The author's dealing with language generates a postmodern treatment that puts an end to conventional ideologies and pays lip service to postcolonial linguistic Africanization. Achebe will not use English to hide the reality of the colonizer. However, language is used to reflect the deprivation and beauty of African surroundings. 
Devices like metaphors and similes are used to highlight the traumatic conditions of Igbo society. Hyperbole, which is a significant tool in African tradition, is also foregrounded. The use of these technical features provides Achebe's text with a typical linguistic status. For instance, the following hyperbole: "a bowl of pounded yam can throw him in a wrestling match" (Achebe 1996, p. 47) signifies the linguistic peculiarity of African text as well as context. It is a text rich with codes which reflect the technical and unfamiliar discursive behavior. Some metaphors include: "Amalinze the cat" (Achebe 1996, p. 8), and "python the sky" (Achebe 1996, p. 118). In this sense, these devices are incorporated to clearly delineate the life of Igbo in a subversive manner so as to criticize the colonial tyrannical events. To put it briefly, by resorting to the appropriated English language, Achebe wants entirely to present the picture of the pre-colonial Igbo society in a transparent and obvious way. Then, Achebe's verisimilitude boosts his critical, deconstructive and constructive intention.

Furthermore, Achebe's ironic discourse is conspicuous in the novel. It is plausible through the actions of the two missionaries. For example, the white man seeks to spread his own culture within the African culture and Mr. Brown yearns to the same devise conflict among the Ibo people. In fact, whiteness: "is very clever. He came quietly and peaceably with his religion. We were amused at his foolishness and allowed him to stay. Now he has won our brothers, and our clan can no longer act like one. He has put a knife on the things that held us together and we have fallen apart" (Achebe 1996, p. 152). The tenor is that both of them hide a particular target. Mr. Brown's softness is meant to seduce and convert people to Christianity. Mr. Smith's tyrannical attitude serves the same goal which is the destruction of the Nigerian tribe. Thus, Achebe exemplifies them to satirize the colonial power and show its destructive purpose.

With the use of the English native language, the author delineates the life of Igbo society. In the beginning of the novel, African stories and dialects narrate and expose all the nine villages of Umuofia. However, as the novel develops and white missionaries begin arriving in Umuofia along with their government and an institution, Achebe tries to insert the colonial language so as to introduce the African trauma and protest the pompous presence of whiteness. For instance, Owomoyela (1993) further asserts that:

"Achebe presents a thorough understanding of narrative organisation and style, and a keen observation of and absorption with day-to-day happenings, not through the lenses of the anthropologist, but through the clear insight of one who was involved with and felt at one with his culture while at the same time inculcating western ideas" (Owomoyela 1993, p. 18).

Following this, Achebe appears to be able to fully convince and seduce the universal audience of the colonial pessimistic actions. However, the author's main purpose seems to hint the idea that verbs and proverbs are considered to be the backbone of any cultural, social or literary emancipation. Achebe employs his art to evoke the tormented aspect of human existence. Throughout the novel, the shadow of death looms as an everlasting destiny that condemns the natives. The novelist is committed in a multi-dimensional portrayal of the Igbo people and how 
they endure the destitutions of colonization. This presentation is manifested through Okika's speech. Okika and many others are physically and morally jailed. Achebe attempts to liberate the supposed others so they can constitute their private realm. Thus, the author's language is no longer a historical or apolitical, yet it includes a pristine charge in postcolonial studies. This linguistic energy devises transformation and forges African representation of the colonial tragedy.

\section{Conclusion}

The present study was an attempt to examine Chinua Achebe's Things Fall Apart through the approach of Mikhail Bakhtin's ideas. The endeavor interprets the nature of polyphonic novel and its relevance to post colonialism. Based on the discussion held, it can be deduced that the author's novel is a manifestation of what the colonizers brought about to the Igbo people by denying the chance of cultural negotiation and repressing their dreams and voices. However, one may confirm the fact that the novel includes moments of deciphering the hidden voices in order to reflect the colonial past and foreshadow the way of decolonization for Igbo society. In this sense, the writer weaves this literary work and puts the light on concealed reality in order to portray and establish a postcolonial discourse with strong voices that are able to piece together the broken fragments as well as the fragmented dreams of a denigrated African generation. Finally, it is important to acknowledge that the debate extends beyond the question of tyranny. It seems to be about the construction of post-colonial identities which are able to re-write the historical colonial fallacies. The message is already enclosed in the title of the novel. The author describes in his novel the falling apart of the African tradition. Achebe criticizes the methods that were used by the white colonizers to hinder the African culture and jeopardize African people. Plainly, Achebe's narration prepares the ground for multiplicity, diversity and tolerance.

\section{References}

Achebe C (1996) Things fall apart. Oxford: Heinemann Educational Publishers.

Alimi AS (2012) A study of the use of proverbs as a literary device in Achebe's Things Fall Apart and Arrow of God. International Journal of Academic Research in Business and Social Sciences 2(3): 121-127.

Bakhtin M (1984) Problems of Dostoevsky's poetics. Edited and Translated by Caryl Emerson. University of Minnesota Press: London.

Bass A, Différance JD (1982) Margins of philosophy. Chicago: University of Chicago Press.

Dentith S (1993) Bakhtinian thought: an introductory reader. London: Routledge.

Fanon F (1993) On national culture. In The Wretched of the Earth. London: Harvester Wheatsheaf.

Miller PA, Platter C, Shepherd D, Barta PI (2001) Carnivalizing difference: Bakhtin and the other. London: Routledge.

Owomoyela O (1993) A history of twentieth-century African literatures. Lincoln: University of Nebraska Press. 